\title{
Cholesterol and Triglyceride Levels in Patients with Homozygous Sickle Cell Disease at Campus Teaching Hospital of Lomé (Togo)
}

\author{
Padaro Essohana ${ }^{1,4, *}$, Kueviakoe Irenee Messanh Delagnon ${ }^{1,2,4}$, Feteke Lochina ${ }^{3,4}$, \\ Magnang Hezouwe ${ }^{1,3,4}$, Mawussi Koffi ${ }^{3,4}$, Layibo Yao ${ }^{1,4}$, Dovi Eteh Isac ${ }^{1}$, Segbena Akuete Yvon ${ }^{1,4}$ \\ ${ }^{1}$ Hematology, Campus Teaching Hospital of Lome, Lome, Togo \\ ${ }^{2}$ Hematology, Sylvanus Olympio Teaching Hospital of Lome, Lome, Togo \\ ${ }^{3}$ National Blood Transfusion Centre, Lome, Togo \\ ${ }^{4}$ Faculty of Health Sciences, University of Lome, Lome, Togo
}

Email address:

essohanapadaro@gmail.com (P. Essohana),padarojustin@yahoo.fr (P. Essohana)

${ }^{*}$ Corresponding author

\section{To cite this article:}

Padaro Essohana, Kueviakoe Irenee Messanh Delagnon, Feteke Lochina, Magnang Hezouwe, Mawussi Koffi, Layibo Yao, Dovi Eteh Isac, Segbena Akuete Yvon. Cholesterol and Triglyceride Levels in Patients with Homozygous Sickle Cell Disease at Campus Teaching Hospital of Lomé (Togo). Science Journal of Clinical Medicine. Vol. 5, No. 2, 2016, pp. 24-28. doi: 10.11648/j.sjcm.20160502.13

Received: March 5, 2016; Accepted: March 11, 2016; Published: March 24, 2016

\begin{abstract}
Determine cholesterol and triglyceride levels in patients with homozygous SS sickle cell during intercritical stage and study the influence of vaso-occlusive crisis on their rates. It was a case - control study during 6 month: one group of 70 homozygous SS sickle cell and a second group of 70 apparently healthy controls with normal hemoglobin AA. The average age of patients with sickle cell is 16, $22 \pm 10.44$ years (range 1 year and 40 years) against $28,91 \pm 15,81$ years (range 2 years and 66 years) for the controls. There was a male predominance in sickle cell disease (sex ratio $=1.41$ ) while it was 0.94 for the controls. In the group of patients, about cholesterol, $47(67.14 \%)$ had a low rate, $20(28.57 \%)$ normal rate and $3(4.29 \%)$ a high rate. For control, $24(34.29 \%)$ had a low rate, $25(35.71 \%)$ had at normal rate and $21(30 \%)$ high rate. For HDL cholesterol, among sickle cell, $51(72.86 \%)$ had a low rate, $16(22.86 \%)$ a normal rate and $3(4.28 \%)$ a high rate against respectively $43(61.43 \%), 22$ $(31.43 \%)$ and $5(7.14 \%)$ for controls. The calculation of the value of LDL cholesterol showed that for sickle cell disease, 68 $(97.14 \%)$ had a low rate, $2(2.86 \%)$ against a high rate respectively $49(70 \%)$ and $21(30 \%)$ for witnesses. Triglycerides dosing showed that among the sickle, $5(7.14 \%)$ had a low rate, $56(80 \%)$ normal rate and $9(12,86 \%)$ a high against respectively 5 (7.14\%), $57(81.42 \%)$ and $8(11.42 \%)$ for controls. Analytically, total cholesterol and its derivatives was significantly lower in patients compared to controls. But the difference is not significant at triglycerides level between the two groups. During the study period, 19 patients with sickle cell disease (29.14\%) had at least one pain crisis. The comparison of the value of different lipid fractions shows that there is no significant difference whether patients had or not crisis during the study period. There was a significant decrease in total cholesterol and its fractions (HDL and LDL) in homozygous SS sickle cell. The vaso-occlusive crisis does not affect these lipid parameters. We recommend to complete this preliminary study by a realization on a larger scale, by identifying lipid peroxidation markers of oxidative stress.
\end{abstract}

Keywords: Sickle Cell Anemia, Cholesterol and Fractions, Triglycerides

\section{Introduction}

Sickle cell disease is a genetic disorder caused by a mutation in the gene encoding the beta chain of hemoglobin. This mutation leads to the replacement of a glutamic acid by valine at position 6 in $\beta$ chain ( $\beta 6 \mathrm{Glu}-\mathrm{Val})$ [1]. One of the phenomena associated with sickle cell disease is oxidative stress witch is defined as an imbalance in the balance between antioxidant defense systems and production of reactive oxygen species (ROS). This imbalance between defense 
systems and production of free radicals $(\mathrm{RO}, \mathrm{RCOO}, \mathrm{OH})$ causes biochemical lesions in the body of cells. This lesion has consequences on the molecular level, alterations in the protein level, appearance of cracks at the DNA or cell membranes lesions induced by lipid peroxidation [1].

In sickle cell disease, the symptoms of this lipid peroxidation are dominated by vaso-occlusive painful crises with significant inflammatory response. The repeated vaso-occlusive phenomena are the main cause of morbidity and mortality in Africa. [2] Several studies have been carried out since the second half of the 20th century on lipid parameters that could play an inflammatory role. These studies have reported abnormalities of lipids and lipoproteins in patient's serum with sickle cell disease [3-4]. In Togo, no study has been conducted in this direction.

The aim of our study was to determine changes in total cholesterol, its fractions (HDL and LDL cholesterol) and triglycerides in a cohort of sickle cell anemia SS followed in Campus Teaching hospital of Lomé and study the influence of the occurrence of crises on the variation of these parameters.

\section{Methodology}

Our study was conducted in hematological service of Campus Teaching hospital. It is a case-control and prospective study over a period of 6 months conducted on 140 subjects divided into 2 groups. The first group is 70 homozygous SS sickle cell consists of men and women, with and without chronic complications, not in crisis who came for consultation for their medical care. At baseline, they were not in vaso-occlusive crisis (CVO) and showed no signs of infection. But during the 6 months of the study, when a patient was a CVO, a new levy was done to study the same lipid parameters. The second group consisted of 70 witnesses, men and women apparently healthy volunteers with normal hemoglobin AA who were recruited during a national campaign for sickle cell screening.

Were included in our study: For case (homozygous SS sickle cell disease): all patients of all ages, of both sexes, of all social and professional groups, came to visit. Each patient underwent a complete physical examination, a hemoglobin electrophoresis to confirm the phenotype. For controls: all apparently healthy individuals of all ages, of both sexes, of all social and professional groups, came voluntarily to screening for hemoglobin electrophoresis in Campus Teaching hospital during a national screening campaign of sickle cell anemia. We have not included in our study other forms of sickle cell disease and for the two groups, we have not included those with hypertension, alcohol and tobacco, and women pregnant or taking oral contraceptives and any subject under any other likely drug to disrupt the metabolism of lipoproteins. From a survey sheet we had collected identification data (order number, full name, and profession), the anthropomorphic data (age, gender), laboratory data (hemoglobin electrophoresis, serum lipid fractions rate) and risk behaviors (smoking, alcohol...). After informed, each patient and control signed a consent, and then a venous sample to fasting elbow crease was made.
After coagulation and centrifugation at $3500 \mathrm{rpm}$ for $5 \mathrm{~min}$ of samples, the serum is collected for biochemical tests and treated within 2 hours. The determination of various parameters was carried out on LISA 500 of Hycel *. Total cholesterol, HDL cholesterol (after selective precipitation of lipoproteins by phostungstates light in the presence of $\mathrm{Mg}++$ ) and plasma triglycerides were determined by enzymatic colorimetric techniques. Cholesterol LDL was calculated using the Friedewald equation. LDL cholesteerol $=$ total cholesterol - (HDL cholesterol $+0.2 \times$ triglycerides).

Epi Info version 3-5-1, August 13, 2008 was used to process the data. This software has allowed us to find the mean, standard deviation, frequency, probability of various parameters studied. For statistical considerations, we used ANOVA hypothesis testing for the comparison of two population (parametric tests) whose approach this hypothesis (for the independent variables) is either to decide on the hypothesis Ho (not difference), H1 (there is a difference), to decide the significance (or $\alpha$ risk coefficient), calculate the appropriate statistical test to determine from the tables the value of statistical test (or critical value of $\mathrm{z}$ or $\mathrm{t}$ ) calculated to compare the statistical test and that obtained from the table, then decide to reject or not the null hypothesis and finally a conclusion. In our study we used $\mathrm{Z}$ which is calculated from $\overline{\mathrm{A}}_{1}$ and $\overline{\mathrm{A}}_{2}$, the respective averages of patients and control, from $\mathrm{S} 1$ and $\mathrm{S} 2$ the respective standard deviations and $\mathrm{n}_{1}$ and $\mathrm{n}_{2}$ respective total number of both populations. In decision making (with Zcal $=$ calculated $\mathrm{Z}$ and Zcrit $=$ critical Z 1.96 with $\alpha=0.05)$ if $|\mathrm{Zcal}| \leq \mathrm{Zcrit}$ : rejecting $\mathrm{Ho}$ for $\mathrm{H} 1$ (non-significant difference between both concentrations). But if $|\mathrm{Zcal}| \geq$ Zcrit Ho is accepted (significant difference between both concentrations) [5]

\section{Results}

Our study was focused on 140 subjects with a mean age of $22.57 \pm 13.12$ years (range 1 year and 66 years) with 75 male and 65 female. This population included 70 homozygous SS sickle cell disease (cases) of average age equal to 16, $22 \pm$ 10.44 years (range 1 year and 40 years) and 70 controls with an average age equal to $28 \pm 9115,81$ years (range 2 years and 66 years). There was a predominance of males in the patients with a sex ratio at 1.41 while it was 0.94 for the controls.

Biologically, for total cholesterol, in patients group, 47 $(67.14 \%)$ had a lowest rate, $20(28.57 \%)$ a normal rate and 3 $(4.29 \%)$ a high rate against respectively $24(34.29 \%), 25$ $(35.71 \%)$ and $21(30 \%)$ for controls (Table 1$)$.

Table 1. Distribution of the study population according to total cholesterol rate.

\begin{tabular}{lllllll}
\hline Patients & \multicolumn{5}{l}{ Control } \\
\hline Valeurs & M & F & total & M & F & total \\
\hline Low & $30(73,2 \%)$ & $17(58,6 \%)$ & 47 & $15(44,1 \%)$ & $09(25 \%)$ & 24 \\
Normal & $11(28,8 \%)$ & $09(31,0 \%)$ & 20 & $11(32,4 \%)$ & $14(38,9 \%)$ & 25 \\
High & $00(0,0 \%)$ & $03(10,3 \%)$ & 03 & $08(23,5 \%)$ & $13(36,1 \%)$ & 21 \\
Total & $41(100 \%)$ & $29(100 \%)$ & 70 & $34(100 \%)$ & $36(100 \%)$ & 70 \\
\hline
\end{tabular}


For HDL cholesterol, among patients with sickle cell, 51 $(72.86 \%)$ had a low rate, $16(22.86 \%)$ normal rate and 3 $(4.28 \%)$ high rate against respectively $43(61.43 \%), 22$ $(31.43 \%)$ and $5(7.14 \%)$ for controls. The calculation of the value of LDL cholesterol showed that for sickle cell disease, $68(97.14 \%)$ had a low rate, $2(2.86 \%)$ a high rate against respectively $49(70 \%)$ and $21(30 \%)$ for witnesses. Triglycerides dosing showed that among patients, $5(7.14 \%)$ had a low rate, $56(80 \%)$ normal rate and $9(12,86 \%)$ a high rate against respectively $5(7.14 \%), 57(81,42 \%)$ and 8 $(11.42 \%)$ for the control (Table 2$)$.

Table 2. Distribution of the population of triglycerides function.

\begin{tabular}{lll}
\hline Valeurs & Patients & Witness \\
\hline Males & & \\
Low & $04(9,8 \%)$ & $04(11,8 \%)$ \\
Normal & $35(85,4 \%)$ & $29(85,3 \%)$ \\
High & $02(4,9 \%)$ & $01(2,9 \%)$ \\
Female & & \\
Low & $01(3,4 \%)$ & $01(2,8 \%)$ \\
Normal & $21(72,5 \%)$ & $28(77,8 \%)$ \\
High & $07(24,1 \%)$ & $07(19,4 \%)$ \\
Total & $70(100 \%)$ & $70(100 \%)$ \\
\hline
\end{tabular}

Analytically, the total cholesterol and its derivatives were significantly lower in sickle cell anemia than controls. But the difference is not significant at the level of triglycerides between the two groups. Table 3 shows the comparison of the average of the parameters studied between cases and controls.

Table 3. Average comparison of serum parameters between cases and controls.

\begin{tabular}{lllll}
\hline \multicolumn{2}{l}{ Lipid parameters } & $\begin{array}{l}\text { Average and } \\
\text { standard } \\
\text { deviation (g/l) }\end{array}$ & $\begin{array}{l}\text { absolut } \\
\text { values of } \mathbf{Z} \\
\text { calculated }\end{array}$ & $\begin{array}{l}\text { critical } \\
\text { values of } \\
\mathbf{Z}\end{array}$ \\
\hline $\begin{array}{l}\text { Total } \\
\text { Cholesterol }\end{array}$ & Patients & $1,27 \pm 0,38$ & $5,57^{*}$ & 1,96 \\
Witness & $1,71 \pm 0,54$ & & \\
Cholesterol & Patients & $0,31 \pm 0,12$ & $2,50^{*}$ & 1,96 \\
WDL & Witness & $0,37 \pm 0,16$ & & \\
Cholesterol & Patients & $0,74 \pm 0,34$ & $5,65^{*}$ & 1,96 \\
& Witness & $1,16 \pm 0,52$ & & \\
Triglycerides & Patients & $0,95 \pm 0,45$ & 0,58 & 1,96 \\
\hline
\end{tabular}

* There is a significant difference.

The difference is not significant at the level of triglycerides between the two groups. So sickle cell had a remarkable overall hypocholesterolemia.

During the follow-up period, 19 patients (27.14\%) had a CVO. The study of the influence of CVO on these lipid parameters shows that there is no significant difference between inter critical phase and during the CVO (Table 4).
Table 4. Comparison of different fractions studied in the absence or not of crisis.

\begin{tabular}{|c|c|c|c|c|}
\hline $\begin{array}{l}\text { Parameters } \\
\text { deviation }\end{array}$ & Crisis & $\begin{array}{l}\text { Means and } \\
\text { standard (g/l) }\end{array}$ & $\begin{array}{l}\text { value of } \mathrm{Z} \\
\text { calculed }\end{array}$ & $\begin{array}{l}\text { value of } Z \\
\text { critical }\end{array}$ \\
\hline \multirow{4}{*}{$\begin{array}{l}\text { Total } \\
\text { Cholesterol } \\
\text { HDL } \\
\text { Cholestérol }\end{array}$} & Yes & $1.21 \pm 0.38$ & \multirow{2}{*}{0,78} & \multirow{2}{*}{1,96} \\
\hline & No & $1.29 \pm 0.37$ & & \\
\hline & Yes & $0.28 \pm 0.09$ & \multirow{2}{*}{1,81} & \multirow{2}{*}{1,96} \\
\hline & No & $0.33 \pm 0.13$ & & \\
\hline \multirow{2}{*}{$\begin{array}{l}\text { LDL } \\
\text { Cholestérol }\end{array}$} & Yes & $0.73 \pm 0.33$ & \multirow{2}{*}{0,22} & \multirow{2}{*}{1,96} \\
\hline & No & $0.75 \pm 0.34$ & & \\
\hline \multirow{2}{*}{ Triglycérides } & Yes & $0.88 \pm 0.39$ & \multirow{2}{*}{0,91} & \multirow{2}{*}{1,96} \\
\hline & No & $0.98 \pm 0.46$ & & \\
\hline
\end{tabular}

\section{Discussion}

The population of our study was relatively representative and had the same characteristics as those of all sickle cell regularly monitored at Campus Teaching hospital of Lomé. Furthermore the study was conducted in one of the reference centers for diagnosis and monitoring of sickle cell disease. Moreover, this is the first study of its kind in Togo. The same type of case-control study between sickle cell anemia and normal control was also made by other authors $[3,4,6,7]$

Serum lipids can be determined by numerous methods: the oldest are color, the most practiced are Trinder enzymatic methods. The oxidase enzymatic technique for determination of lipids is accurate, precise and rapid. It is introduced in daily routine in many laboratories for determination of total cholesterol, triglycerides, HDL and other substrates. [8]

The average age of patients with sickle cell disease is 16.22 \pm 10.44 years and extreme values 1 and 40. Our results are consistent with those Kueviakoe et al [9] who found an average age of 18,93ans in the same service during sickle cell anemia. Erasmus et al [3] found a mean age of 10.19 years but their study had been conducted in children.

There was a male predominance with a sex ratio 1.4 in sickle cell disease. This predominance of the male sex was also found by Monnet D et al in Côte d'Ivoire [2] who found a sex ratio of 2.7 in a study of 64 patients with SS sickle cell disease. Zohrsh R. and al. in Iran studies on $24 \mathrm{SS}$ homozygous sickle cell patients, reported 15 male patients against 9 women [10]. Sickle cell disease is transmitted following an autosomal recessive, there is no particular sex predisposition [9]. The decrease in total cholesterol and these fractions is one of disturbances usually observed in sickle cell disease $[3,4]$. This is confirmed by our results that we found a significant decrease in total cholesterol levels in SS sickle cell compared to control. These results are similar to those of Zohreh R. and al [10] in Iran, Monnet D and al in Ivory Coast [6], Erasmus RT and al in Nigeria [3] and al-Hazmi MA [7]. HDL cholesterol in sickle cell is significantly lower than that of control subjects. The same results were found by Seixas MO [11] in Brazil in a study of 152 children. It is the same for other authors. [3, 6, 7]. Serum LDL cholesterol levels in homozygous sickle cell is significantly lower than the controls. The results of Jaimie S. and al [12] on sickle cell and those of Zohreh Rahimi and al [10] are similar to our results. It is the 
same for others $[6,7]$.

Triglycerides dosing showed that among patients, 5 (7.14\%) had a low rate, $56(80 \%)$ normal rate and $9(12,86 \%)$ a high rate against respectively $5(7.14 \%), 57(81.42 \%)$ and 8 $(11.42 \%)$ for controls. The difference is not significant at triglycerides level between the two groups. Patients with cell anemia had a remarkable overall hypocholesterolemia as controls. Our results are similar to those of Erasmus RT and al [3] in which the difference is very significant. It is the same for Zohreh R. and al [10] in Iran who found in sickle cell anemia an overall normal triglyceride levels. But Monnet D and his colleagues [2] in Ivory Coast found hypertriglyceridemia in sickle cell anemia. In another study, the same authors had already found a significantly higher triglyceride levels in homozygous SS sickle cell disease compared to controls.

The study of the influence of CVO on these lipid parameters shows that there is no significant difference between inter critical phase and during the CVO. Most writers have made the same observations and especially since the assays were done during inter critical phase $[36,7]$. These different results found in homozygous sickle cell disease could be caused by disorders of different sources of supply triglycerides. Another possible explanation is that these results could be due to the activity of lipoprotein lipase in the process of oxidative stress [13].

Sickle cell generates oxidative stress responsible for the membrane lipid peroxidation $[14,15]$. This peroxidation also interested plasma lipids and lipoproteins. Hypocholesterolemia could be the consequence of the increased use of plasma cholesterol to the recovery of the injured erythrocyte membrane by lipid peroxidation [16]. It was suggested that the metabolism of lipids and lipoproteins should be modified in sickle cell anemia. The decline in the volume of red blood cells in the blood of these patients leads to higher plasma volume throught dilution of plasma components including lipids and lipoproteins $[4,12]$. It was suggested in sickle cell anemia that reducing cholesterol synthesis will result in a limited rate of the enzyme $\beta$-hydroyl-methyl-glutarul-CoA reductase [12]. Lecithin Down: the activity of cholesterol acyltransferase (LCAT) is one of mechanisms included in the reduction of cholesterol in sickle cell disease. The preferred lipoprotein by human LCAT is HDL. LCAT catalyzes the esterification of plasma cholesterol and prefers the lecithin molecules of the major HDL phospholipid, which contains polyunsaturated fatty acids $[12,17]$. The reduction of HDL concentration and n-3 polyunsaturated fatty acids in serum phospholipids of SS sickle cell anemia has been reported in Nigeria $[12,17,18]$. Also, a significant decrease of polyunsaturated fatty acids in erythrocyte of sickle cell anemia patients was found [19]. It was suggested that the elongation and desaturation of fatty acids are disrupted in sickle cell disease [20].

\section{Conclusion}

There is significant decrease in total cholesterol and its fractions HDL and LDL in sickle cell homozygotes SS compared to normal controls AA. The existence or not of crisis did not influence the variation of parameters. We recommend to complete this by achieving a larger scale, by identifying lipid peroxidation markers of oxidative stress.

\section{References}

[1] Girot R, P Begue, Galacteros F. Sickle. Paris 2003; Ed John Libbey. P1-41.

[2] Monnet D Edjeme NE, N'Dri K-Hauhouot Attoungbré ML Ahibo H, Sangare A, AE Yapo.. Lipoprotein (a) and proteins of the acute phase inflammatory in homozygous sickle cell crisis. Annales de Biologie Clinique. Volume 60, Number 1, 101-3, Janier - February 2002.

[3] Erasmus RT, Olukoga AO, Ojuawo O. Plasma lipids and lipoproteins in Nigerian children with sickle cell anemia. Ann Trop Paediatr. 1990; 10 (4): 421-3.

[4] Al-Hazmi MA Jabbar FA, Warsy AS. Cholesterol and triglyceride level in patients with sickle cell anemia. Scand J Clin Lab Invest. 1987 Jun; 47 (4): 351-4.

[5] Ossey GE. Statistical methods applied to research. During ESTBA 4th year (2009).

[6] Monnet D, F Kane, Konan Waidhet D, F Diafouka, Sangare A, AE Yapo. Lipid, apolipoprotein AI and B levels in patients with sickle cell Ivorian anaemia. Ann Biol Clin (Paris). 1996; 54 (7): 285-8.

[7] El-Hazmi MA Jabbar FA, Warsy AS. Cholesterol and triglyceride level in patients with sickle cell anemia. Scand J Clin Lab Invest. 1987 Jun; 47 (4): 351-4.

[8] Faouzia M, Ilhem H, N Fadoua Hichem M Mohamed FN. Evaluation of an enzymatic colorimetric technique for the assay of cholesterol. French magazine laboratories: Vol 39, No. 412, May 2009. pp 63-66.

[9] Kueviakoe MI, N'Zouonta V Agbetiafa K, E Padaro, Vovor A Segbena AY. Influence of hemoglobin F on the evolutionary profile of homozygous sickle cell disease in Togo. J. Rech. Sci. Univ. Lome (Togo), 2010, Series D, 12 (2): 243-248.

[10] Zohreh R, M Ahmad Mansour H, M Hamid Mansour R, Ronald I, Nage L. Plasma lipid in Iranians with sickle cell disease: hypocholterolemia in sickle anemia and Increase of HDL-cholesterol in sickle cell trait. Clinica Chimica Acta 365 (2006) 2220.

[11] Seixas MO, Rocha LC, MB Carvalho, JF Menezes, Lyra IM, VM Nascimento Couto RD, Atta AM Reis MG, MS Goncalves Levels of high-density lipoprotein cholesterol (HDL-C) Among children with steady-state sickle cell disease. Lipids Health Dis. 2010 Aug 27; 9: 91. doi: 10.1186/1476-511X-9-91.

[12] Jamie Shores, John Peterson, Dorothy V, Robert HG. Reduced cholesterol levels in African-American adults with sickle cell disease. J. Natl Med Assoc 2003; 95: 813-7.

[13] Lazarevic JL, Swedire WL. Dyslipoproteinemia in the course of active arthritis rheumathoid. Semin Arthr Rheum 1992, 22: 172-82.

[14] Hebbel RP, JW Eaton, Batasingam M, Steinberg MH. Spontaneous oxygen radical generation by sickle erythrocytes. J Clin Invest 1982; 70: 1253-5. 
[15] Rice-Evans C, Omorphos SC, E. Baysal Sickle cell membranes and oxidative damage. Biochem J 1986; 237: 265-9.

[16] Hajjar KA, Gavish D, J Breslow, R. Nachman Lipoprotein (a) modulation of endothelial cell surface of fibrinolysis and Its potential role in atherosclerosis. Nature 1989; 339: 303-5.

[17] Natio HK. Coronary artery disease and disorders of lipid metabolism. In: Kaplan LA, weighing AJ, kazmierezak SC, editors. Clinical Chemistry: Theory, analysis, correlation. St Louis: Mosby; 2003. p. 603-38.

[18] HR Glew, Casados JK Huang YS, Chuang LT, Vanderjagt DJ.
The fatty acid composition of the serum phospholipids of children with sickle cell disease in Nigeria. Prostaglandins Leukot Essent Fat Acids 2002; 67: 217-22.

[19] Musket FD, muskiet FA. Lipids, fatty acids and trace Elements in plasma and erythrocytes of podiatric patients with homozygous sickle cell disease. Acta Clin Chem 1984; 142: $1-10$.

[20] Enomoto TM Isichei C Vanderjagt DG, Fry DE, RH Glew. Decreased polyunsaturated fatty acids in sickle cell anemia. $\mathrm{J}$ Trop Pediatr 1998; 44: 28-34. 